\title{
TSAR MIKHAIL ROMANOV: HIS ENTRY INTO POWER
}

\author{
Andrej P. Pavlov \\ Saint Petersburg State University, Saint Petersburg, Russian Federation
}

\begin{abstract}
Introduction. As historical literature shows, the election of Tsar Mikhail Romanov at the Zemsky Sobor of 1613 occurred without broad support of boyars and nobles. The Cossacks played a decisive role in his election. This article is devoted to considering the issue of how Tsar Mikhail was able to establish himself in power. Methods and materials. The article is based on the use and comprehensive analysis of the sources, which show the process of approval of Tsar Mikhail Romanov in power. The article uses narrative and documentary sources, including new archival materials. The article contains a critical comparison of official and unofficial sources. The author of the article uses the principles of historicism and system analysis. The article considers the events of 1613 in their development and interrelations, and provides a comprehensive analysis of various political and socio-economic phenomena that contributed to Tsar Mikhail's power strengthening. The article uses the methods of genealogical research and textual analysis of sources. Analysis. On March 14, 1613, Tsar Mikhail, after much persuasion, agreed to accept the throne in Kostroma, but he didn't hurry to move to Moscow. He arrived in Moscow only on May 2, 1613. It was necessary to strengthen the authority of the royal power, to establish relations with social classes and, above all, with the ruling elite. The author of the article shows that Tsar Mikhail and his entourage coped very successfully with these problems during the march from Kostroma to Moscow. The control over the government, the initiative of operational assignments and solutions of land affairs gradually concentrated in the hands of the tsar. The author shows that Mikhail entered Moscow as an absolute sovereign and that there is no reason to talk about restricting his power in favor of the Boyar Duma and the Zemsky Sobor. During 1613-1618 the composition of the Duma and court ranks was intensively replenished by the Romanovs. Results. The author comes to the conclusion that during the first years of Mikhail Fedorovich's reign the position of the House of Romanov in the state was significantly strengthened.

Key words: Mikhail Romanov, the House of Romanov, Zemsky Sobor, the Time of Troubles, ruling elite, boyar aristocracy, Boyar Duma, sovereign's court.

Citation. Pavlov A.P. Tsar Mikhail Romanov: His Entry into Power. Vestnik Volgogradskogo gosudarstvennogo universiteta. Seriya 4, Istoriya. Regionovedenie. Mezhdunarodnye otnosheniya [Science Journal of Volgograd State University. History. Area Studies. International Relations], 2019, vol. 24, no. 2, pp. 147-157. (in Russian). DOI: https://doi.org/10.15688/jvolsu4.2019.2.13
\end{abstract}

УДК 94(47)046

ББК $63.3(2) 4$

Дата поступления статьи: 05.12.2018 Дата принятия статьи: 02.03.2019

\section{ЦАРЬ МИХАИЛ РОМАНОВ: ВХОЖДЕНИЕ ВО ВЛАСТЬ}

\author{
Андрей Павлович Павлов \\ Санкт-Петербургский государственный университет, г. Санкт-Петербург, Российская Федерация
}

Аннотация. В исторической литературе убедительно показано, что избрание царя Михаила Романова на Земском соборе 1613 г. состоялось без широкой поддержки со стороны боярской знати и дворянства и решающую роль в его избрании сыграли выступления казачества. Но каким образом царю Михаилу удалось утвердиться у власти? Рассмотрению данного вопроса посвящена настоящая статья. 14 марта 1613 г. в Костроме избранный царь Михаил после долгих уговоров дал согласие принять царство. Однако он отнюдь не спешил с переездом в Москву, куда он прибыл только 2 мая 1613 года. Необходимо было укрепить авторитет 
царской власти, наладить взаимоотношение с сословиями и, прежде всего, с правящей элитой. Автор статьи показывает, что с решением данных проблем царь Михаил и его окружение во время похода из Костромы в Москву справились весьма успешно. Постепенно в руках царя сосредоточивались контроль над органами государственного управления, инициатива служебных назначений и решения земельных дел. Автор показывает, что царь Михаил въехал в Москву как полновластный государь и что нет оснований говорить об ограничении его власти в пользу Боярской думы и Земского собора. В 1613-1618 гг. состав думных и придворных чинов интенсивно пополнялся людьми романовского круга. Автор приходит к выводу о том, что уже в первые годы царствования Михаила Федоровича произошло существенное укрепление положения династии Романовых в государстве.

Ключевые слова: Михаил Романов, династия Романовых, Земский собор, Смутное время, правящая элита, боярская аристократия, Боярская дума, государев двор.

Цитирование. Павлов А. П. Царь Михаил Романов: вхождение во власть // Вестник Волгоградского государственного университета. Серия 4, История. Регионоведение. Международные отношения. - 2019. T. 24, № 2. - C. 147-157. - DOI: https://doi.org/10.15688/jvolsu4.2019.2.13

Введение. В исторической литературе благодаря исследованиям Г.А. Замятина, А.Л. Станиславского, Р.Г. Скрынникова, И.О. Тюменцева, В.Н. Козлякова, Д.В. Лисейцева и других историков утвердилась справедливая в целом точка зрения о том, что избрание царя Михаила Федоровича Земским собором 21 февраля 1613 г. произошло без широкой поддержки со стороны боярской знати и значительной части дворянства; видную (если не решающую) роль в деле царского избрания сыграли выступления казачества и московского простонародья $[10 ; 11 ; 15 ; 16 ; 21$; $29 ; 32 ; 36]$. Данная ситуация свидетельствует о том, что Русское государство еще не вышло из состояния Смуты. Но каким образом новоизбранному юному царю Михаилу удалось утвердиться у власти? Рассмотрению этого вопроса посвящена настоящая статья.

Методы и материалы. Статья написана на основе привлечения и комплексного анализа всей совокупности сохранившихся источников, освещающих процесс утверждения у власти избранного царя Михаила Романова. Использованы данные как нарративных, так и документальных источников, в том числе новые архивные материалы. Произведено критическое сопоставление сообщений официальных и неофициальных источников. При написании статьи применены принципы историзма и системности - события 1613 г. рассматриваются в их развитии и взаимосвязи, дается комплексный анализ различных политических и социально-экономических явлений, способствовавших вхождению во власть царя Михаила Романова. Использованы методы ис- торико-генеалогических изысканий, текстологического анализа источников.

Анализ. Избрание Михаила Федоровича на царство не привело автоматически к ликвидации политического кризиса. В сложной обстановке протекала присяга новоизбранному царю в Москве и провинции. Согласно показаниям ряда источников, многие представители знати были недовольны избранием Михаила Романова, плели против него интриги и были вынуждены присягнуть ему только под давлением казаков [3, с. 27; 10, с. 73-74; 16 , с. $15 ; 25$, с. 95]. Но после принятия присяги царю Михаилу его противники смирились со своим поражением. Свидетельством этому может служить тот факт, что под окружными грамотами Земского собора на места от 25 февраля 1613 г., излагавших проромановскую версию царского избрания, в числе прочих стояли и подписи лиц, которые не являлись сторонниками избрания Михаила Романова на Земском соборе - руководителей «Совета всея земли» кн. Д.Т. Трубецкого и кн. Д.М. Пожарского, а также старых бояр князей Ф.И. Мстиславского, И.В. Голицына и И.С. Куракина [6, л. 77-90 об.; 12, с. 188$191 ; 18$, с. 305-306].

После 25 февраля 1613 г. были прекращены полномочия временного земского правительства - «Совета всея земли» во главе с Д.Т. Трубецким и Д.М. Пожарским [18, с. 231$232 ; 35$, с. XXV]. Власть на Москве перешла к традиционной Боярской думе. Произошло и восстановление традиционной иерархии внутри Боярской думы во главе с ее «первым» боярином кн. Ф.И. Мстиславским. 
2 марта 1613 г. в Кострому к новоизбранному царю Михаилу Федоровичу было отправлено от Земского собора посольство с целью уговорить его принять царство [26, c. 198]. Состав посольства не был случайным. В числе тех, кто поддерживал на Земском соборе кандидатуру Михаила Романова, был глава посольства боярин Ф.И. Шереметев. Сторонниками Михаила были и другие члены посольства. Был связан с романовским кланом боярин кн. Вл.И. Бахтеяров-Ростовский $[20$, c. $73-74]$. Окольничий Ф.В. Головин принадлежал к роду, имевшему тесные родственные связи с Романовыми (дочь Петра Ивановича Головина Анастасия, жена боярина кн. А.Б. Горбатого-Суздальского, была родной бабкой Федора Никитича Романова). Участники посольства в Кострому архиепископ Феодорит, келарь Троице-Сергиева монастыря Авраамий Палицын и архимандрит Новоспасского монастыря Иосиф 21 февраля выступали на Красной площади перед народом как сторонники Михаила Романова [10, с. 55, 58; 28 , с. 340]. Авраамий Палицын проявил себя как активный участник агитационной кампании в пользу избрания Романова на царский престол [28, с. 231-233].

13 марта посольство прибыло в Кострому, а 14 марта послы вели переговоры с Михаилом Федоровичем и его матерью старицей Марфой Ивановной. Только после долгих уговоров Михаил дал согласие принять царство, a его мать дала на это свое благословение.

19 марта царь Михаил со своим окружением выехал из Костромы в Ярославль, где он задержался больше чем на месяц (с 21 марта по 16 апреля). В Москву же он прибыл только 2 мая. Эта задержка не была случайной. Положение новоизбранного царя в государстве оставалось непрочным. Предстояло укрепить авторитет царской власти, наладить взаимоотношение с сословиями и, прежде всего, с правящей элитой - государевым двором, восстановить разрушенное в годы Смуты дворцовое хозяйство.

Представление о направлениях политики царя Михаила и его окружения во время похода на Москву, о его взаимоотношениях с руководством Земского собора и Боярской думой дают дошедшие до нас материалы переписки между царем и московскими властя- ми в марте - начале мая 1613 г. [7, стб. 10411216]. Еще находясь в Костроме, царь Михаил потребовал от московских властей присылки государственной печати и боярского подлинного списка [7, стб. 1048], что говорит о намерении царя и его окружения взять под свой контроль государственное управление. В руках царя стала постепенно сосредоточиваться инициатива назначений воевод. По прибытии в Ярославль царь отпустил от себя воевод кн. С.В. Прозоровского и Л.А. Вельяминова против «немецких людей» под Псков [7, стб. 90; 26, с. 243]. Царем были назначены воеводы в Казань, Свияжск, Алатырь, Арзамас, Бежецкий Верх и другие города [7, с. 1124, 1139]. Бояре были вынуждены полностью признать прерогативу государя в сфере воеводских назначений ${ }^{1}$, что способствовало укреплению его власти на местах.

В царском стане в период похода на Москву был образован приказ Большого дворца, главой которого стал близкий родственник матери царя Михаила Борис Михайлович Салтыков [7, стб. 1140]. Главной задачей приказа Б.М. Салтыкова было восстановление разоренного в годы Смуты дворцового хозяйства. Прибывший от царя в Москву посланник кн. Иван Федорович Троекуров поставил перед властями Земского собора вопрос о мерах по восстановлению фонда дворцовых земель, которые в широких масштабах раздавались в годы Смуты служилым людям.

Для ревизии земельных владений членов государева двора был составлен земляной боярский список (список членов государева двора с указанием размеров и происхождения их земельных владений), который являлся действующим документом весной 1613 г. [4; 17]. Постепенно решение земельных вопросов переходило к государю и его окружению. 8 апреля царь отправил грамоту в Москву, в которой запретил властям Земского собора «до нашего (государева. - А. П.) указу» отнимать поместья и вотчины у стольников, стряпчих, дворян и «всяких чинов людей» [7, стб. 1100]. 28 апреля 1613 г. от имени царя Михаила Федоровича Боярской думе была отправлена грамота с предписанием оставить за дьяком Михаилом Даниловым вотчину, пожалованную ему при царе Василии [7, стб. 1167-1170]. 
Сосредоточение в руках царя Михаила инициативы служебных назначений и решения земельных вопросов способствовало усилению зависимости дворян от царской власти. В ставку государя прибывает основная часть членов государева двора. Царским указом предписывалось «стольником, и стряпчим, и жильцом быть на нашей службе с нами в походе к Москве» [7, стб. 1145-1146]. В списках дворовых, которые не явились в царский стан, оказались лишь двое стольников, трое стряпчих и 37 жильцов [7, стб. 1147-1148]. Московские власти сообщали в своих отписках царю, что «на Москве людей мало: стольники и стряпчие, и дворяне, и жильцы все у государя» и «в воеводы послать некого» [7, стб. 1126, 1131].

Вокруг царя в его походной ставке сплачивается определенный правительственный кружок, на формирование которого большое влияние оказывала мать Михаила Федоровича инока Марфа Ивановна. Первенствующее положение в этом кружке заняли племянники Марфы братья Борис и Михаил Михайловичи Салтыковы [37]. Первый из них, как упоминалось выше, стал главой Дворцового приказа, а второй исполнял видную придворную должность кравчего ${ }^{2}$. В состав вновь образованного правительственного кружка вошли кн. Афанасий Васильевич Лобанов-Ростовский, получивший чин чашника ${ }^{3}$, и родственник старицы Марфы Ивановны Константин Иванович Михалков, исполнявший обязанности постельничего ${ }^{4}$.

В составе окружения царя Михаила во время его похода на Москву находились члены посольства в Кострому - бояре Ф.И. Шереметев, кн. Вл.И. Бахтеяров-Ростовский и окольничий Ф.В. Головин, которые выступали в роли посредников в сношениях царя с московскими властями и выполняли роль своего рода походной Думы [7, стб. 1091, 1092, 11551168, 1183, 1184].

Мы видим, таким образом, что во время похода на Москву царь Михаил сосредоточивает в своих руках полноту власти в стране, и с этим были вынуждены считаться даже его политические противники.

2 мая 1613 г. царский поезд въехал в Москву. По случаю приезда царя был отслужен торжественный молебен в Успенском соборе, после которого чины Московского государства принесли присягу на верность службы новому государю [7, стб. 89-90].

До сих пор спорным в историографии остается вопрос об ограничительной записи царя Михаила, которая якобы была дана им при вступлении на царский престол. В рамках настоящей статьи нет возможности подробно остановиться на рассмотрении данной проблемы. Выскажем лишь некоторые соображения.

Каких-либо указаний о существовании «ограничительной записи» царя Михаила Федоровича в утвержденной грамоте 1613 г. и в другой современной официальной документации мы не встречаем. Известия о «Записи», которая была дана царем Василием Шуйским боярам и «земле», имеются в грамотах, рассылаемых по его воцарении на места [2, с. 102; 30, с. 299]. Однако никаких следов присяги царя Михаила подданным в грамотах на места по случаю его вступления на престол мы не обнаруживаем [6, л. 77-90 об.; 7, стб. 45$51 ; 12$, с. $188-191 ; 18$, с. 305-306].

Трудно согласиться с мнением В.О. Ключевского о существовании некого соглашения на царя с боярами во время собора, которое обеспечивало гарантии подданным от монаршего произвола $[13$, с. 78]. Во время избирательного собора Михаила Федоровича не было в столице. Встреча царя Михаила с руководством Боярской думы и Земского собора состоялась только в начале мая, когда царь в окружении своего двора въехал в Москву как полновластный государь. В такой обстановке ни Боярская дума, ни Земский собор не могли принудить царя к подписанию какой-либо ограничительной записи. Нельзя исключить, впрочем, что какие-то обещания со стороны царя Михаила своим подданным имели место. Но они не были оформлены в виде письменного акта и носили, скорее всего, форму устных деклараций. Можно предположить, что какие-то обязательства «блюсти и жаловать» подданных «по суду и по правде» Михаил Федорович дал в своей «тронной речи» во время венчания на царство. Об этих обязанностях монарха говорил в своем поучении царю во время коронации Казанский митрополит Ефрем, тогдашний главный иерарх русской церкви [31, с. 81$]$. Но в поучении митрополита 
Ефрема, по справедливому замечанию В.Н. Козлякова, речь шла о нравственном императиве поведения христианского монарха, а отнюдь не о политическом ограничении его власти [15, с. 51-52]. Таким образом, если даже имели место какие-то обещания царя Михаила своим подданным (данные, скорее всего, в устной форме) касательно способов его будущего правления, мы не имеем оснований говорить об ограничении его власти в пользу Боярской думы и Земского собора.

Важную роль в утверждении царя Михаила Федоровича на престоле сыграла выработка основного соборного документа - утвержденной грамоты, в которой обосновывались его права на царство. Как и в грамоте об избрании на престол Бориса Годунова (служившей одним из главных источников при составлении утвержденной грамоты 1613 г.), в грамоте об избрании Михаила Федоровича подчеркивается именно самодержавный характер власти выбранного на Земском соборе монарха, ее преемственность от прежних «прирожденных» государей рода Ивана Калиты. При этом в грамоте об избрании Михаила Романова эта линия проводится гораздо более полно и последовательно, чем в утвержденной грамоте об избрании Годунова. Утвержденная грамота 1613 г. последовательно проводит идею кровного родства Михаила с прежней династией Калитовичей. Михаил Федорович именуется здесь как «царский сродник», «племянник» и «ближний приятель» царя Федора Ивановича (а отсюда и законный наследник прежнего благочестивого «царского корени»). Становление и развитие официальной романовской концепции о царе Михаиле Федоровиче как близком родственнике («племяннике») и «ближнем приятеле» царя Федора Ивановича обстоятельно изучено В.Д. Назаровым [19]. Преимуществом кровного родства с прежними «прирожденными» государями не обладали ни царь Борис Годунов, ни царь Василий Шуйский. Учитывая данное обстоятельство, составители утвержденной грамоты 1613 г. рассматривали в противовес царю Михаилу его предшественников - Бориса Годунова и Василия Шуйского - только как «избранных», а не как «прирожденных» государей ${ }^{5}$.

Утверждению у власти царя Михаила Федоровича в значительной мере способство- вало то обстоятельство, что недовольные его избранием на престол представители знати и дворянства не могли создать единой сплоченной оппозиции.

Между традиционной Боярской думой, большинство членов которой находилось в свое время в оккупированном Кремле, и руководством земских ополчений существовали серьезные противоречия. Если положение в государстве старого руководства Боярской думы основывалось на силе традиции и прочных корпоративных связях внутри боярской элиты, то позиции земских воевод подкреплялись прежде всего их авторитетом и влиянием в армии. В руках последних и после избрания на престол Михаила Федоровича некоторое время сохранялась определенная военная власть в столице. Кн. Д.Т. Трубецкому и кн. Д.М. Пожарскому продолжали подчиняться особые воинские подразделения 6 .

Популярности Трубецкого и Пожарского в служилой среде способствовала политика широких земельных раздач, проводившаяся руководством I и II ополчений и объединенным «Советом всея земли». Земские власти осуществляли раздачи как дворцовых и черных земель, так и владений бояр и дворян, служивших королю Сигизмунду ${ }^{7}$. Участникам освобождения Москвы земские власти в качестве вознаграждения за службы («за очищение Москвы») практиковали переводы части их поместных земель в вотчины, подобно тому, как жаловались вотчины «за московское осадное сидение» при царе Василии Шуйском ${ }^{8}$. О масштабах земельных раздач, осуществленных земскими правительствами, можно судить по тому факту, что из названных в земляном боярском списке 1613 г. членов государева двора почти у половины (у 70 с лишним из 160 человек) встречаются записи о пожалованиях им поместий и вотчин «при боярех» (то есть руководством I и II ополчений и объединенного «Совета всея земли») [4, с. 1-24].

Широкий размах земельных пожалований участникам ополчений вызывал тревогу и недовольство старых бояр, в большинстве своем сидевших при оккупационной власти в Кремле. Результатами политики земских властей, приведшей к значительному истощению фонда дворцовых земель $[27$, с. 6-7; 33, 
c. 121-122], было обеспокоено и само правительство царя Михаила Федоровича. Царь и руководство Боярской думы вынуждены были считаться со сложившимся положением, учитывая большое влияние Д.Т. Трубецкого и Д.М. Пожарского в армии.

Осенью 1613 г. расстановка сил в столице изменилась в связи с походом русского войска во главе с Д.Т. Трубецким под Новгород против шведов [7, стб. 104, 107-109]. Воспользовавшись моментом, Боярская дума 30 ноября 1613 г. приняла приговор, один из пунктов которого предписывал аннулировать вотчины, пожалованные «за московское очищенье», и переводить их в поместья в соответствии с поместными окладами [9, с. 82]. Принятие Приговора 30 ноября 1613 г. существенно подрывало позиции в государстве земских воевод. Серьезный урон авторитету кн. Д.Т. Трубецкого был нанесен в результате его неудачного похода против шведов. Ходили слухи о том, что московские бояре, сидевшие ранее в осаде в Москве вместе с поляками, из-за «ненависти» к Трубецкому, который «снискал уважение у всего народа за осаду и взятие Москвы», сознательно отправили его под Новгород с небольшим войском, чтобы он мог «осрамиться» [3, с. 32]. В первые годы царствования Михаила Федоровича Д.Т. Трубецкой уходит в тень придворной жизни. Он незанимает ответственных постов, не упоминается ни как глава московских приказов, ни как участник переговоров с иностранными послами ${ }^{9}$. От государственных дел в начале царствования Михаила Романова отходит кн. Д.М. Пожарский. С декабря 1613 г. он на полтора года, вплоть до июня 1615 г., как отметил Ю.М. Эскин, перестает упоминаться на царской службе [7, стб. 120$123,181-182 ; 14$, стб. 48,$49 ; 38$, с. 116-117].

Падение положения руководителей земских ополчений не привело, однако, к торжеству старой думской аристократии, утратившей в годы Смуты былой авторитет в обществе и внутреннее корпоративное единство. В годы царствования Михаила Федоровича представители первостепенной княжеской знати, бывшие члены «Семибоярщины» (князья Ф.И. Мстиславский, И.М. Воротынский, И.В. Голицын, И.С. Куракин, А.В. Трубецкой), существенной роли в делах государственного управления не играли [24, с. 737-738].
Наличие серьезных противоречий между старым руководством Боярской думы и лидерами земского движения, упадок авторитета и влияния в годы Смуты старой думской аристократии способствовали приходу к власти придворной группировки родственников и фаворитов матери царя Михаила старицы Марфы Ивановны во главе с Салтыковыми. Этот придворный клан благодаря своей сплоченности и поддержке матери царя сумел занять первенствующее положение при дворе в начале царствования Михаила Романова. В 1613-1618 гг. происходило интенсивное обновление состава Боярской думы и придворных чинов за счет родственников Романовых и людей, близких к романовскому клану ${ }^{10}$.

Результаты. Утверждению у власти царя Михаила Федоровича Романова, избрание которого на Земском соборе произошло без широкой поддержки со стороны боярской знати и дворянства под давлением казачества, способствовал ряд факторов. Следует отметить, прежде всего, продуманную политику, проводимую окружением царя Михаила во время его двухмесячного похода из Костромы на Москву, в результате которой в руках царя стали сосредоточиваться контроль над государственным управлением, инициатива служебных назначений и решения земельных дел. Все это способствовало укреплению авторитета царской власти, консолидации дворянства (и, прежде всего, его верхушки - членов государева двора) вокруг трона. 2 мая 1613 г. Михаил Федорович в окружении царского двора въехал в Москву как полновластный государь. Видную роль в укреплении власти Михаила Федоровича сыграла разработка концепции его вступления на престол, в основе которой лежала идея его кровного родства с династией Калитовичей - в официальной документации царь Михаил именуется как «царский сродник», «племянник», «ближний приятель» царя Федора Ивановича и, следовательно, представляется как законный преемник власти прежних «прирожденных» государей. Важным фактором, способствовавшим утверждению на престоле Михаила Романова, явилось отсутствие единства среди представителей знати, недовольных его избранием на царство. Серьезные противоречия существовали между руководством традицион- 
ной Боярской думы и лидерами земских ополчений. В сложившейся обстановке единственной сплоченной политической силой, способной взять бразды управления страной, оказался придворный клан родственников и фаворитов матери царя Михаила во главе с Салтыковыми. Таким образом, уже к концу первого года царствования Михаила Федоровича произошло существенное укрепление положения династии Романовых в государстве. И хотя, как справедливо отмечают современные исследователи, Смута продолжалась еще несколько лет, 1613 г. стал важной вехой в преодолении политического кризиса начала XVII века.

\section{ПРИМЕЧАНИЯ}

1 «И мы, холопи твои, - писали царю бояре 11 апреля 1613 г., - в городы воевод и для казачьих кормов сборщиков посылать без твоего государева указу не смеем, потому что нам, холопем твоим, про то не ведомо: в которые городы от тебя государя воеводы и для кормов сборщики отпущены, и о том, нам, холопем своим, вели свой государев указ учинити» [7, стб. 1106].

2 Упоминается как кравчий в земляном списке 1613 г., который был действующим документом в апреле - мае этого года [4, с. 3]. Официально чином кравчего М.М. Салтыков был пожалован в 7122 (1613/14) г. [7, стб. 136].

3 Значится как чашник в земляном боярском списке 1613 г. [4, с. 4].

${ }^{4}$ Как постельничий К.И. Михалков упоминается во время церемонии венчания на царство Михаила Федоровича 11 июля 1613 г. [31, с. 84]. Официально чин постельничего был утвержден за ним в 1613/14 (7122) г. [7, стб. 132].

5 Об идеологии утвержденной грамоты об избрании на престол Михаила Романова подробнее см.: [22].

${ }^{6}$ В апреле 1613 г., накануне вступления в Москву царя Михаила, Д.Т. Трубецкой и Д.М. Пожарский били ему челом о дозволении им и «всем ратным людям», принимавшим участие в освобождении Москвы, участвовать во встрече государя и «видеть царские очи» [7, стб. 1207-1208]. 28 апреля 1613 г. царю Михаилу бил челом есаул «полку боярина и воеводы князя Дмитрея Тимофеевича Трубецкого» Иван Данилов о пожаловании его брата, участвовавшего в штурме Китай-города [34, с. 11].

7 Так, по грамоте от имени воевод І ополчения от 17 июня 1611 г. вотчина служившего королю Сигизмунду боярина кн. И.С. Куракина сельцо Во- ронино Костромского у. была отдана кн. Д.М. Пожарскому [1, с. 270].

8 Упоминания о пожалованиях земскими воеводами вотчин «за московское очищение» см.: [4, c. $1,5,6,9,11,12,14,19 ; 5$, с. $88 ; 8$, c. $450,453,455,459]$.

9 Подробнее о судьбе Д.Т. Трубецкого см.: [23].

10 Подробнее об этом см.: [24].

\section{СПИСОК ЛИТЕРАТУРЫ}

1. Акты служилых землевладельцев XV - начала XVII века. T. III / сост. А. В. Антонов. - М. : Древлехранилище, 2002. - 680 с.

2. Акты, собранные в библиотеках и архивах Российской империи Археографическою экспедициею Императорской Академии наук : в 4 т. Т. 2. СПб. : Тип. ІІ отд-ния Собственной Е.И.В. канцелярии, 1836. $-417 \mathrm{c}$.

3. Арсеньев, В. Арсеньевские шведские бумаги. 1611-1615 гг. / В. Арсеньев // Сборник Новгородского общества любителей древностей. - Новгород, 1911. - Вып. 5. - С. I-XI, 1-120.

4. Барсуков, А. П. Докладная выписка 121 (1613) г. о вотчинах и поместьях / А. П. Барсуков // Чтения в Обществе истории и древностей российских при Московском университете. - М. : Университетская типография, 1895. - Кн. І. - Отд. І. C. I-VIII, 1-24.

5. Боровский уезд в XVII веке (материалы дозора 1613 г.) / подгот. С. С. Ермолаев. - М. : Российский государственный архив Древних актов, 1992. $-138 \mathrm{c}$.

6. Грамота от Земского собора на Колу от 25 февраля 1613 г. // Архив СПбИИ РАН. - Ф. 238. Оп. 1. - № 292. - Л. 77-90 об.

7. Дворцовые разряды. Т. І. - СПб.: Тип. II отд-ния Собственной Е.И.В. канцелярии, 1850. C. I-XXXVI, стб. 1-1234.

8. Дозорная книга Силы Никитича Грекова и подьячего Климентия Козодавлева поместно-вотчинных земель Нижегородского уезда 1612/13 г. // Материалы по истории Нижегородского края конца XVI - первой четверти XVII века. Ч. I. - М. : Древлехранилище, 2015. - С. 411-495.

9. Законодательные акты Русского государства второй половины XVI - первой половины XVII века : тексты. - Л. : Наука, 1986. - 264 с.

10. Замятин, Г. А. К истории Земского собоpa 1613 г. / Г. А. Замятин // Труды Воронежского государственного университета. Т. III. - Воронеж : Изд-во Воронеж. гос. ун-та, 1926. - С. 1-74.

11. Замятин, Г. А. Россия и Швеция в начале XVII века. Очерки политической и военной истории / Г. А. Замятин. - СПб. : Европейский Дом, 2008. -494 c. 
12. Зимин, А. А. Акты Земского собора $1612-$ 1613 гг. / А. А. Зимин // Записки Отдела рукописей Гос. библиотеки СССР им. В.И. Ленина. Вып. 19. М. : [б. и.], 1957. - С. 188-192.

13. Ключевский, В. О. Курс русской истории. Ч. 3 // Сочинения : в 8 т. Т. 3 / В. О. Ключевский. М. : Гос. изд-во полит. лит., 1957. - 427 с.

14. Книги разрядные. Т. I. - СПб. : Тип. II отдния Собственной Е.И.В. канцелярии, 1853. - С. ІXV.-Стб. 48, 49.

15. Козляков, В. Н. Михаил Федорович/ В. Н. Козляков. - М. : Молодая гвардия, 2004. - 347 с.

16. Лисейцев, Д. В. Демократия Смутного времени. Как проходил Земский собор 1613 года / Д. В. Лисейцев // Родина. - 2013. - № 2. - С. 14-17.

17. Лукичев, М. П. О «земляном» боярском списке 1613 г. / М. П. Лукичев // Исследования по источниковедению истории СССР дооктябрьского периода : сб. ст. - М. : Ин-т истории СССР АН СССР, 1983. - C. 103-111.

18. Любомиров, П. Г. Очерки истории Нижегородского ополчения 1611-1613 гг. / П. Г. Любомиров. - Переиздание. - М. : Соцэкгиз, 1939. - 343 с.

19. Назаров, В. Д. «Ближний приятель» царя Федора Ивановича - Михаил Романов. Как конструировался начальный миф Романовых / В. Д. Назаров // 400-летие дома Романовых: политика памяти и монархическая идея, 1613-2013 : сб. ст. - СПб. : Изд-во Европейского университета в Санкт-Петербурге, 2016. - С. 23-49.

20. Павлов, А. П. Государев двор и политическая борьба при Борисе Годунове (1584-1605 гг.) / А. П. Павлов. - СПб. : Наука, 1992. - 280 с.

21. Павлов, А. П. К вопросу о характере представительства на Земском соборе 1613 г. / А. П. Павлов // Кафедра истории России и современная отечественная историческая наука. - СПб. : Издательский Дом Санкт-Петербургского государственного университета, 2012. - С. 446-464. - (Труды кафедры истории России с древнейших времен до XX века. Т. III).

22. Павлов, А. П. К истории утвержденной грамоты 1613 г. / А. П. Павлов // Вестник СанктПетербургского университета. История. - 2015. Вып. 3. - С. 11-20.

23. Павлов, А. П. Князь Д.Т. Трубецкой и внутриполитическая борьба в Русском государстве в начале царствования Михаила Романова / А. П. Павлов // Русский сборник. Вып. 5. - Брянск : Курсив, 2009. - С. 157-165. - (Труды кафедры отечественной истории древности и средневековья Брянского государственного университета им. акад. И.Г. Петровского. Вып. 12).

24. Павлов, А. П. Правящие круги России на завершающем этапе Смутного времени / А. П. Павлов // Вестник Санкт-Петербургского университета. История. - Т. 63, вып. 3. -2018. - С. 729-747.
25. Повесть о Земском соборе 1613 года / публ., подгот. к печати А. Л. Станиславский, Б. Н. Морозов // Вопросы истории. - 1985. - № 5. - С. 89-96.

26. Разрядные книги 1598-1638 гг. - М. : Ин-т истории СССР АН СССР, 1974. - 398 с.

27. Седашев, В. Н. Очерки и материалы по истории землевладения Московской Руси в XVII в. / В. Н. Седашев. - М. : Типолитография В. Рихтер, 1912. - C. I-IV, 1-226.

28. Сказание Авраамия Палицына. - М. ; Л. : Изд-во АН СССР, 1955. - 344 с.

29. Скрынников, Р. Г. Михаил Романов / Р. Г. Скрынников. - М. : АСТ : Ермак, 2005. - 334 с.

30. Собрание государственных грамот и договоров, хранящихся в Государственной коллегии Иностранных дел. Ч. ІІ. - М. : Тип. Селивановского, 1819. $-612 \mathrm{c}$.

31. Собрание государственных грамот и договоров, хранящихся в Государственной коллегии Иностранных дел. Ч. ІІІ. - М. : Тип. Селивановского, 1822. $-540 \mathrm{c}$.

32. Станиславский, А. Л. Гражданская война в России XVII в.: Казачество на переломе истории / А. Л. Станиславский. - М. : Мысль, 1990. - 272 с.

33. Сташевский, Е. Д. Очерки по истории царствования Михаила Федоровича. Ч. I / Е. Д. Сташевский. - Киев : Тип. 2-й Артели, 1913. - С. 1-387, ILVI.

34. Сухотин, Л. М. Первые месяцы царствования Михаила Федоровича (Столбцы Печатного приказа) / публ. Л. М. Сухотина. - М. : Синодальная тип., 1915. - C. I-XXIV, 1-238.

35. Сухотин, Л. М. Четвертчики Смутного времени (1604-1617 гг.) / публ. Л. М. Сухотина. - М. : Синодальная типография, 1912. - C. I-XXVII, 1-403.

36. Тюменцев, И. О. Из истории избирательного Земского собора 1613 г. / И. О. Тюменцев // Дом Романовых в истории России. - СПб. : Изд-во С.-Петерб. ун-та, 1995. - С. 74-82.

37. Щербачев, О. В. О родстве Салтыковых с Михаилом Федоровичем Романовым / О. В. Щербачев // Летопись Историко-Родословного общества в Москве. - М. : Энциклопедия российских деревень, 1995. - Вып. 3 (47). - С. 62-67.

38. Эскин, Ю. М. Дмитрий Михайлович Пожарский / Ю. М. Эскин. - М. : Квадрига : Зебра Е, 2013. $-352 \mathrm{c}$.

\section{REFERENCES}

1. Antonov A.V., ed. Akty sluzhilykh zemlevladeltsev XV-nachala XVII veka. T. III [Acts of Serving Landowners of the $15^{\text {th }}-$ the Early $17^{\text {th }}$ Century. Vol. III]. Moscow, Drevlekhranilishche Publ., 2002. $680 \mathrm{p}$. 
2. Akty, sobrannye v bibliotekakh i arkhivakh Rossiyskoy imperii Arkheograficheskoyu ekspeditsieyu Imperatorskoy Akademii nauk: $v 4 t$. T. 2 [Acts Collected in Libraries and Archives of the Russian Empire by the Archaeografical Expedition of the Imperial Academy of Sciences. In 4 vols. Vol. 2]. Saint Petersburg, Tipografiya II otdeleniya Sobstvennoy E.I.V. kantselyarii, 1836. 417 p.

3. Arsenyev V. Arsenyevskie shvedskie bumagi. 1611-1615 gg. [The Swedish Papers by Arsenyev. 1611-1615]. Sbornik Novgorodskogo obshchestva lyubiteley drevnostey [The Collection of the Novgorod Society of Antiquity Lovers]. Novgorod, 1911, iss. 5, pp. I-XI, 1-120.

4. Barsukov A.P. Dokladnaya vypiska 121 (1613) g. o votchinakh i pomestyakh [Report Extract of 121 (1613) on Patrimonies and Estates]. Chteniya $v$ Obshchestve istorii $i$ drevnostey rossiyskikh pri Moskovskom universitete [Readings in the Imperial Society of Russian History and Antiquities at the Moscow University]. Moscow, Universitetskaya tipografiya, 1895. Book 1, Otd. 1, pp. I-VIII, 1-24.

5. Ermolaev S.S., ed. Borovskiy uezd v XVII veke (materialy dozora 1613 g.) [Borovskiy Uezd in the $17^{\text {th }}$ Century (Materials of the Patrol of 1613)]. Moscow, Rossiyskiy gosudarstvennyy arkhiv Drevnikh aktov Publ., 1992. 138 p.

6. Gramota ot Zemskogo sobora na Kolu ot 25 fevralya $1613 \mathrm{~g}$. [Letter from the Zemsky Sobor to Kola Dated 25 Feb. 1613]. Arkhiv SanktPeterburgskogo instituta istorii Rossiyskoy akademii nauk [Archive of Saint Petersburg Institute of History, Russian Academy of Sciences], F. 238, Op. 1, no. 292, L. 77-90 ob.

7. Dvortsovye razryady. T. I [Palace Charges. Vol. 1]. Saint Petersburg, Tipografiya II otdeleniya sobstvennoy E.I.V. kantselyarii, 1850, pp. I-XXXVI, col. 1-1234.

8. Dozornaya kniga Sily Nikiticha Grekova i podyachego Klimentiya Kozodavleva pomestnovotchinnykh zemel Nizhegorodskogo uezda 1612/13 g. [Patrol Book of Estate and Patrimonial Lands of Nizhny Novgorod Uezd of 1612/13 by Sila Nikitich Grekov and Clerk Clementy Kozodavlev]. Materialy po istorii Nizhegorodskogo kraya kontsa XVI - pervoy chetverti XVII veka. Ch. I [Materials on the History of Nizhny Novgorod Krai of the Late $16^{\text {th }}-$ the First Quarter of the $17^{\text {th }}$ Century. Part I]. Moscow, Drevlekhranilishche Publ., 2015, pp. 411-495.

9. Zakonodatelnye akty Russkogo gosudarstva vtoroy poloviny XVI - pervoy poloviny XVII veka: teksty [Legislative Acts of the Russian State of the Second Half of the $16^{\text {th }}-$ First Half of the $17^{\text {th }}$ Century: Texts]. Leningrad, Nauka Publ., 1986. 264 p.

10. Zamyatin G.A. K istorii Zemskogo sobora 1613 g. [To the History of the Zemsky Sobor of 1613].
Trudy Voronezhskogo gosudarstvennogo universiteta. T. 3 [The Works of Voronezh State University. Vol. 3]. Voronezh, Izd-vo Voronezhskogo gosudarstvennogo universiteta, 1926, pp. 1-74.

11. Zamyatin G.A. Rossiya i Shvetsiya v nachale XVII veka. Ocherki politicheskoy $i$ voennoy istorii [Russia and Sweden in the Early $17^{\text {th }}$ Century. Essays on Political and Military History]. Saint Petersburg, Evropeyskiy Dom Publ., 2008. 494 p.

12. Zimin A.A. Akty Zemskogo sobora 1612 $1613 \mathrm{gg}$. [Acts of the Zemsky Sobor of 1612-1613]. Zapiski Otdela rukopisey Gosudarstvennoy biblioteki SSSR im. V.I. Lenina. Vyp. 19 [The Notes of the Departament of Manuscripts of the State V.I. Lenin Library. Iss. 19]. Moscow, 1957, pp. 188-192.

13. Klyuchevskiy V.O. Kurs russkoy istorii. Ch. 3 [Course of Russian History. Part 3]. Klyuchevskiy V.O. Sochineniya: $v 8$ t. T. 3 [Works. In 8 vols. Vol. 3]. Moscow, Gosudarstvennoe izdatelstvo politicheskoy literatury, $1957.427 \mathrm{p}$.

14. Knigi razryadnye. T. I [Charge Books. Vol. I]. Saint Petersburg, Tipografiya II otdeleniya Sobstvennoy E.I.V. kantselyarii, 1853, pp. I-XV, col. 48, 49.

15. Kozlyakov V.N. Mikhail Fedorovich. Moscow, Molodaya gvardiya Publ., 2004. 347 p.

16. Liseytsev D.V. Demokratiya Smutnogo vremeni. Kak prokhodil Zemsky sobor 1613 goda [Democracy of the Time of Troubles. How the Zemsky Sobor of 1613 Passed]. Rodina, 2013, no. 2, pp. 14-17.

17. Lukichev M.P. O «zemlyanom» boyarskom spiske 1613 g. [On the "Land" Boyar List of 1613]. Issledovaniya po istochnikovedeniyu istorii SSSR dooktyabrskogo perioda: sb. st. [Research on the Source Study of the USSR History before the October Period. Collection of Articles]. Moscow, Institut istorii SSSR AN SSSR Publ., 1983, pp. 103-111.

18. Lyubomirov P.G. Ocherki istorii Nizhegorodskogo opolcheniya 1611-1613 gg. [The Essays on the History of the Nizhny Novgorod Militia, 1611-1613]. Moscow, Sotsekgiz Publ., 1939. 343 p.

19. Nazarov V.D. «Blizhniy priyatel» tsarya Fedora Ivanovicha - Mikhail Romanov. Kak konstruirovalsya nachalnyy mif Romanovykh [Mikhail Romanov as a "Close Friend" of Tsar Fedor Ivanovich. How the Initial Myth of the Romanovs Was Constructed]. 400-letie doma Romanovykh: politika pamyati i monarkhicheskaya ideya, 1613-2013: sb. st. [The 400th Anniversary of the House of the Romanovs: the Policy of Memory and the Monarchical Idea, 1613-2013. Collected Articles]. Saint Petersburg, Izd-vo Evropeyskogo universiteta v Sankt-Peterburge, 2016, pp. 23-49.

20. Pavlov A.P. Gosudarev dvor i politicheskaya borba pri Borise Godunove (1584-1605 gg.). [Sovereign's Court and the Political Struggle under Boris 
Godunov(1584-1605)]. Saint Petersburg, Nauka Publ., 1992. 280 p.

21. Pavlov A.P. K voprosu o kharaktere predstavitelstva na Zemskom sobore $1613 \mathrm{~g}$. [On the Nature of Representation at the Zemsky Sobor of 1613]. Kafedra istorii Rossii i sovremennaya otechestvennaya istoricheskaya nauka [The Chair of Russian History and Modern Russian Historical Science]. Saint Petersburg, Izdatelskiy Dom Sankt-Peterburgskogo gosudarstvennogo universiteta, 2012, pp. 446-464. (Trudy kafedry istorii Rossii s drevneyshikh vremen do XX veka. T. III [Works of the Department of Russian History from Ancient Times to the $20^{\text {th }}$ Century. Vol. III]).

22. Pavlov A.P. K istorii utverzhdennoy gramoty $1613 \mathrm{~g}$. [More on the History of the Utverzhdennaya Gramota of 1613]. Vestnik Sankt-Petersburgskogo universiteta. Istoriya [Vestnik of Saint Petersburg University. History], 2015, iss. 3, pp. 11-20.

23. Pavlov A.P. Knyaz D.T. Trubetskoy i vnutripoliticheskaya borba v Russkom gosudarstve $\mathrm{v}$ nachale tsarstvovaniya Mikhaila Romanova [Prince D.T. Trubetskoy and the Internal Political Struggle in the Russian State at the Beginning of the Reign of Mikhail Romanov]. Russkiy sbornik. Vyp. 5 [Russian Collection. Iss. 5]. Bryansk, Kursiv Publ., 2009, pp. 157-165. (Trudy kafedry otechestvennoy istorii drevnosti i srednevekovya Bryanskogo gosudarstvennogo universiteta im. I.G. Petrovskogo. Vyp. 12 [Works of the Department of Domestic History of Antiquity and the Middle Ages of the Bryansk State University Named after Academician I.G. Petrovsky. Iss. 12]).

24. Pavlov A.P. Pravyashchie krugi Rossii na zavershayushchem etape Smutnogo vremeni [The Ruling Circles of Russia in the Final Stage of the Time of Troubles]. Vestnik Sankt-Petersburgskogo universiteta. Istoriya [Vestnik of Saint Petersburg University. History], 2018, vol. 63, iss. 3, pp. 729-747.

25. StanislavskiyA.L., Morozov B.N., eds. Povest o Zemskom sobore 1613 goda [The Story of the Zemsky Sobor of 1613]. Voprosy istorii, 1985, no. 5, pp. 89-96.

26. Razryadnye knigi 1598-1638 gg. [Charge Books of 1598-1638]. Moscow, Institut istorii SSSR AN SSSR Publ., 1974. 398 p.

27. Sedashev V.N. Ocherki i materialy po istorii zemlevladeniya Moskovskoy Rusi v XVII v. [Essays and Materials on the History of Landownership of Moscow Russia in the $17^{\text {th }}$ Century]. Moscow, Tipolitografiya V. Rikhter, 1912, pp. I-IV, 1-226.

28. Skazanie Avraamiya Palitsyna [The Story by Abrahamiy Palitsyn]. Moscow; Leningrad, Izd-vo AN SSSR, 1955. 344 p.
29. Skrynnikov R.G. Mikhail Romanov [Mikhail Romanov]. Moscow, AST Publ., Ermak Publ., 2005. $334 \mathrm{p}$.

30. Sobranie gosudarstvennykh gramot $i$ dogovorov, khranyashchikhsya $v$ Gosudarstvennoy kollegii Inostrannykh del. Ch. 2 [Collection of State Certificates and Treaties, Stored in the State Collegium of Foreign Affairs. Part 2]. Moscow, Tipografiya Selivanovskogo, 1819. 612 p.

31. Sobranie gosudarstvennykh gramot $i$ dogovorov, khranyashchikhsya $v$ Gosudarstvennoy kollegii Inostrannykh del. Ch. 3 [Collection of State Certificates and Treaties, Stored in the State Collegium of Foreign Affairs. Part 3]. Moscow, Tipografiya Selivanovskogo, 1822.540 p.

32. Stanislavskiy A.L. Grazhdanskaya voyna v Rossii XVII v.: Kazachestvo na perelome istorii [Civil War in Russia of the $17^{\text {th }}$ Century: Cossacks at the Turning Point of History]. Moscow, Mysl Publ., 1990. $272 \mathrm{p}$.

33. Stashevskiy E.D. Ocherki po istorii tsarstvovaniya Mikhaila Fedorovicha. Ch. I [Essays on the History of the Reign of Mikhail Fedorovich. Part I]. Kiev, Tipografiya 2-y Arteli, 1913, pp. 1-387, I-LVI.

34. Sukhotin L.M. Pervye mesyatsy tsarstvovaniya Mikhaila Fedorovicha (Stolbtsy Pechatnogo prikaza) [The First Months of the Reign of Mikhail Fedorovich (Prikaz of the Seal Columns)]. Moscow, Sinodalnaya tipografiya, 1915, pp. I-XXIV, $1-238$.

35. Sukhotin L.M. Chetvertchiki Smutnogo vremeni (1604-1617 gg.) [Chetvertchiki of the Time of Troubles (1604-1617)]. Moscow, Sinodalnaya tipografiya, 1912, pp. I-XXVII, 1-403.

36. Tjumencev I.O. Iz istorii izbiratelnogo Zemskogo sobora $1613 \mathrm{~g}$. [From the History of the Electoral Zemsky Sobor of 1613]. Dom Romanovykh v istorii Rossii [House of the Romanovs in the History of Russia]. Saint Petersburg, Izd-vo SanktPeterburgskogo universiteta, 1995, pp. 74-82.

37. Shcherbachev O.V. O rodstve Saltykovykh s Mikhailom Fedorovichem Romanovym [On the Relationship of the Saltykovs with Mikhail Fedorovich Romanov]. Letopis Istoriko-Rodoslovnogo obshchestva v Moskve [Chronicle of the Historical and Genealogical Society in Moscow]. Moscow, Entsiklopediya rossiyskikh dereven Publ., 1995, iss. 3 (47), pp. 62-67.

38. Eskin Yu.M. Dmitriy Mikhaylovich Pozharskiy. Moscow, Kvadriga Publ., Zebra E Publ., 2013.352 p. 


\section{Information about the Author}

Andrej P. Pavlov, Doctor of Sciences (History), Professor, Department of Russian History from the Ancient Times to the Twentieth Century, Institute of History, Saint Petersburg State University, Universitetskaya Emb., 7-9, 199034 Saint Petersburg, Russian Federation; Leading Researcher, Saint Petersburg Institute of History, RAS, Petrozavodskaya St., 7, 197110 Saint Petersburg, Russian Federation, a.pavlov@spbu.ru, https://orcid.org/0000-0002-5952-0858

\section{Информация об авторе}

Андрей Павлович Павлов, доктор исторических наук, профессор кафедры истории России с древнейших времен до XX века Института истории, Санкт-Петербургский государственный университет, Университетская наб., 7-9, 199034 г. Санкт-Петербург, Российская Федерация; ведущий научный сотрудник, Санкт-Петербургский институт истории РАН, ул. Петрозаводская, 7, 197110 г. Санкт-Петербург, Российская Федерация, a.pavlov@spbu.ru, https://orcid.org/0000-0002-5952-0858 